DEMOGRAPHIC RESEARCH

VOLUME 34, ARTICLE 6, PAGES 175-202

PUBLISHED 22 JANUARY 2016

http://www.demographic-research.org/Volumes/Vol34/6/

DOI: 10.4054/DemRes.2016.34.6

Research Article

Gender inequalities in employment and wageearning among internal labour migrants in

Chinese cities

Min Qin

James J. Brown

Sabu S. Padmadas
Bohua Li

Jianan Qi

Jane Falkingham

(c) 2016 Min Qin et al.

This open-access work is published under the terms of the Creative Commons Attribution NonCommercial License 2.0 Germany, which permits use, reproduction \& distribution in any medium for non-commercial purposes, provided the original author(s) and source are given credit.

See http://creativecommons.org/licenses/by-nc/2.0/de/ 


\section{Table of Contents}

1 Introduction 176

$2 \quad$ Background and research context 177

3 Data 180

$4 \quad$ Methodology 181

5 Results 183

5.1 Descriptive 183

$\begin{array}{lll}5.2 & \text { Probit regression analysis } & 187\end{array}$

5.3 Evidence of sample selection effects 189

5.4 OLS results after the adjustment of sample selection 192

5.5 Decomposition results 192

6 Discussion 193

$7 \quad$ Acknowledgements $\quad 195$

$\begin{array}{ll}\text { References } & 196\end{array}$

$\begin{array}{ll}\text { Appendix A } & 201\end{array}$

$\begin{array}{ll}\text { Appendix B } & 202\end{array}$ 


\title{
Gender inequalities in employment and wage-earning among internal labour migrants in Chinese cities
}

\author{
Min Qin ${ }^{1}$ \\ James J. Brown ${ }^{2}$ \\ Sabu S. Padmadas ${ }^{3}$ \\ Bohua $\mathrm{Li}^{4}$ \\ Jianan $Q \mathbf{i}^{5}$ \\ Jane Falkingham ${ }^{6}$
}

\begin{abstract}
BACKGROUND

Recent trends show an unprecedented feminisation of migration in China, triggered by the increasing demand for cheap labour in big cities and the availability of women in the labour market. These trends corroborate the evidence that non-agricultural work and remittance from urban labour migrants have become the major sources of rural household income.
\end{abstract}

\section{OBJECTIVE}

This paper investigates the extent of gender inequalities in job participation and wage earning among internal labour migrants in China. We hypothesize that female migrants in cities are economically more disadvantaged than male migrants in the job market.

\section{METHODS}

We use data from the 2010 National Migrant Dynamics Monitoring Survey conducted in 106 cities representing all 31 provinces and geographic regions. The study applies the standard Heckman two-step Probit-OLS method to model job participation and wage-

\footnotetext{
${ }^{1}$ China Population and Development Research Centre (Beijing) and China Research Centre, University of Southampton, UK.

${ }^{2}$ School of Mathematical and Physical Sciences, University of Technology Sydney, Australia.

${ }^{3}$ Corresponding author: Centre for Global Health, Population, Poverty \& Policy, China Research Centre and Department of Social Statistics and Demography, University of Southampton, UK.

E-Mail: S.Padmadas@soton.ac.uk.

${ }^{4}$ China Population and Development Research Centre (Beijing), China.

${ }^{5}$ China Population and Development Research Centre (Beijing), China.

${ }^{6}$ ESRC Centre for Population Change and China Research Centre, University of Southampton, UK.
} 
Qin et al.: Gender inequalities in employment and wage-earning among internal labour migrants

earning, separately for 59,225 males and 41,546 females aged 16-59 years, adjusting for demographic and social characteristics and potential selection effects.

\section{RESULTS}

Female migrants have much lower job-participation and wage-earning potential than male migrants. Male migrants earn 26\% higher hourly wages than their female counterparts. Decomposition analysis confirms potential gender discrimination, suggesting that $88 \%$ of the gender difference in wages (or $12 \%$ of female migrant wage) is due to discriminatory treatment of female migrants in the Chinese job market. Migrants with rural hukou status have a smaller chance of participation in the job market and they earn lower wages than those with urban hukou, regardless of education advantage.

\section{CONCLUSIONS}

There is evidence of significant female disadvantage among internal labour migrants in the job market in Chinese cities. Household registration by urban and rural areas, as controlled by the hukou status, partly explains the differing job participation and wage earning among female labour migrants in urban China.

\section{Introduction}

Economic migration in China, particularly since the beginning of this century has been unprecedented in scale. The 2010 census data show that China has over 220 million people who have migrated from rural to urban areas, of which the share in big cities is as high as $30-40 \%$ (NBS 2011). The official estimates show that, in 2011, approximately 159 million internal labour migrants were from rural areas, accounting for about $12 \%$ of China's total population (NBS 2012).

The migration trends observed over the last two decades also reveal an emerging pattern of feminisation in China (Fan 2008; Liang and Chen 2004). At the national level, the sex ratio of migrants was around 125 males per 100 females in 1990, which dropped to 107 and 100 in 2000 and 2005 respectively (Duan, Zhang, and Lu 2010). Overall, females represented over $50 \%$ of internal labour migrants in the last decade (NBS 2012). This change has been prompted by the availability of cheap labour and increasing demand for female workforce in service sectors, manufacturing in non-state owned industries, and household service jobs in big cities (Lu and Wang 2013). There has also been a shift in the female migration patterns from intra-provincial to interprovincial, increasingly longer times at destinations, as well as high levels of circulatory migration due to restrictions in big cities (Davin 2005; Liang and Chen 2004; Fan 2004; Fan 2000). Economic motives explain much of the recent increase in female migration 
from rural to urban areas and cities, rather than family or social factors (Taylor 2011). Young Chinese women increasingly aspire to better education opportunities, autonomy, urban experience, modernity and a better life in cities (Chiang, Hannum, and Kao 2013; Liang and Chen 2004; Eklund 2000).

This paper aims to investigate the extent of gender inequalities in job participation and wage earning among internal labour migrants in China. Within the context of increasing feminisation of internal migration, this research addresses a policy-oriented question: are migrant women vulnerable to discrimination in job-participation and wage-earning in Chinese cities? We hypothesize that female migrants in cities are economically more disadvantaged than male migrants in the job market. This research applies the widely used Heckman two-step model to cross-sectional data from a large nationally representative migrant survey conducted in 2010 across 106 Chinese cities, covering all 31 provinces and geographical regions. The 2010 National Migrant Dynamics Monitoring Survey (NMDMS) is the first of its kind in China in terms of study design, sample size and comprehensive coverage of migrant population at the national level. It should to be noted that using standard OLS regression to estimate factors associated with the distribution of wages might not be appropriate due to potential selection bias. This is because the wages of migrants who are either unemployed or those seeking jobs at the time of survey are unobserved. The proposed Heckman two-step solution is therefore appropriate to overcoming the selection bias problem.

\section{Background and research context}

Rural-urban migration in China was initially restricted until the late 1970s through the hukou registration system. Subsequently, the introduction of market-oriented economic reforms, including the establishment of special economic zones and open coastal cities in pursuit of attracting foreign investments generated steady growth in economic opportunities and industrial productivity across China. Most economic activities were concentrated in big cities and in adjacent urban areas, thus creating demand for both skilled and unskilled labour migrants from the countryside (Cai, Lin, and Cao 2009). Therefore, since the mid-1990s, there has been a structural transformation in the Chinese economy towards liberalization and privatization of the state-owned companies, which not only sparked the expansion of private sectors, but also created new economic opportunities for the surplus rural workforce (Knight, Deng, and Li 2010; Cai, Lin, and Cao 2009).

Although rural migrants have contributed significantly to China's economic

growth, they have low social status in urban cities. For instance, they tend to work 
mostly in informal sectors and usually have limited access to social benefits relating to unemployment, health and pension insurance, which are available to their urban counterparts. Efforts by the central government to eliminate discrimination against migrants, through new laws and regulations to protect migrants' basic rights and increase their access to urban services and social benefits, have had limited success (Smart and Smart 2001). Migrants are generally willing to work for low wages in cities and urban areas, and they usually surrender to unequal treatment and discriminatory practices for their jobs and earnings. Of particular interest to this study, with increasing feminisation of migration, the gender gap in wages has widened considerably across big cities and urban areas of China (Sutherland and Yao 2011).

According to the Global Wage Report 2014/15, women's average wages range from $4 \%$ to $36 \%$ less than men's wages across countries; however, the gap widens in absolute terms for higher-earning women (ILO 2015). Evidence from meta-analysis found that from the 1960s to the 1990s, in spite of a significant gender wage inequality, there was a moderate equalization in wages between the men and women over time the ratio of male to female wages declined by $0.8 \%$ per year during this period (Weichselbaumer and Winter-Ebmer 2005; Jarrell and Stanley 2004; Stanley and Jarrell 1998). The gender wage gap is diverse across countries during the transition from planned to market economies (Brainerd 2000). For instance, the gender wage gap was increasing in Russia and Ukraine, but decreasing in Central and Eastern European countries. In East Asia, however, the gender gap in wages is highly pronounced: females earn much lower wages (50\% or less) than their male counterparts in Japan, Malaysia, Korea and Singapore; about 66\% less in Hong Kong, the Philippines, Thailand, China and Viet Nam. In addition, while the gender gap in wages has been slowly narrowing in recent decades in this region, the opposite is the case for China (including Hong Kong) and Japan (ILO 2008).

Researchers often define wage discrimination by comparing wages for equally productive workers. The most standard approach in the literature to estimate the gap is the Blinder-Oaxaca decomposition method (Oaxaca 1973). The crude wage gap is decomposed into the portion explained by differences in human capital endowments, and an unexplained part, which is the difference in the human capital prices. It is the unexplained portion of the wage differential that is often interpreted as an estimate of discrimination. For example, the gender discrimination in wages was estimated at $6 \%$ in the United States in 2003 (Jarrell and Stanley 2004). In East Asia, discrimination contributed to between $20 \%$ and $80 \%$ of the gender gap in wages (ILO 2008).

In China, the 1994 Labour Law states that 'women and men shall enjoy equal rights with respect to employment; women may not be refused employment because of their sex' and furthermore, 'equal pay shall be given for equal work'. However, the enforcement of gender equality legislation has been weak. With rapid economic growth, 
substantial and varying gender inequalities of employment and pay have emerged (Sutherland and Yao 2011; Lin et al. 2008; Shen and Yao 2008). Studies of unemployment among the general population reported evidence of female disadvantages (Cai 2004; Knight and Li 2001). These studies show that women's reemployment decisions are likely to be influenced by life-cycle characteristics of the household. Another study conducted between 1988 and 1995 in 10 provinces of urban China reported a moderate increase in gender wage gap as the economic planning shifted from central to local areas (Gustafsson and Li 2000). During this period, females earned between $16 \%$ and $18 \%$ less than males which thereafter increased to between 23\% and 30\% from 1990 to 2000 (ACWF 2006; Gustafsson and Li 2000). The decomposition results showed an intensification of discrimination from $52 \%$ to $63 \%$ of the gender gap in wages during 1988-1995 to 78\% in 2007 (Gustafsson and Li 2000; Li and Song 2012). However, these results apply generally to urban hukou residents and not specifically the internal labour migrants.

The gender difference in wages can be explained by individual, employee, wagerelated and productivity-related characteristics, for example age, education, years spent in employment, hours worked, and type of sector (Weichselbaumer and Winter-Ebmer 2005; Kunze 2008; Kunze 2005; Garcia, Hernández, and Lopez-Nicolas 2001; Stanley and Jarrell 1998). Small-scale and regional surveys demonstrate evidence of gender inequalities amongst internal migrants in the Chinese labour market (Zhang and Dong 2008; Bishop, Luo, and Wang 2005; Liang and Chen 2004). Female migrants generally earn lower wages than their male counterparts, even after controlling for other sociodemographic and family variables (Duan, Zhang, and Lu 2010; Wang 2010). However, the gender wage gap was not uniform across migrants' wages distribution (Wang 2010; Magnani and Zhu 2012). Human capital and migrant characteristics have positive influence on the wage-earning (Wang and Cai 2008). Young, unmarried, well-educated and urban-household-registered migrants generally had better earning potential than their rural, less educated, older counterparts. Inter-province migration, longer residence in urban areas and employment-driven migration are also significantly associated with higher income (Duan, Zhang, and Lu 2010). A study by Ge, Li, and Yin (2010) in Jiangsu province reported that type of city was the most significant factor influencing the job opportunity and wages of female migrants. The jobs in cities required specific skills for which education and work experience were less relevant, which enabled wider opportunities for migrant workers. The government even introduced welfare packages and minimum wage standards for migrant workers, especially in coastal cities (Cai 2011; Knight, Deng, and Li 2010; Du and Pan 2009). Yet, the wage differences continued to rise, disadvantaging female labour migrants living in urban areas (Gustafsson and Li 2000). 


\section{Data}

Existing studies focus mostly on urban hukou employees. There is little populationbased research examining the gender gap in employment and wages for migrants in urban areas. The present research addresses this gap using 2010 NMDMS, which covers 106 cities representing all 31 provinces and geographical regions with a focus on labour migrants from rural areas of China.

The 2010 NMDMS was funded by the then National Population and Family Planning Commission and coordinated by the China Population and Development Research Centre. The survey interviewed 122,670 male and female internal labour migrants. The individuals eligible for the survey were migrants aged between 16 and 59 years, who had moved across a county (Xiàn) boundary from their registered household and had stayed in the current destination for more than one month. In addition, the eligibility criteria included the reasons for moving, which was to seek a paid job. The spouses of migrants were not included in the eligibility criteria. The 106 cities were chosen purposively, ensuring a representation of different administrative levels (province, prefecture, and county) and special economic zones. Within each city, a three-stage (township, community, individual) probability proportional to size (PPS) sampling method was adopted. Although the 106 cities were purposively chosen, within each city the sample was drawn randomly from the migrant populations resulting in high coverage of the migrant population across China.

Of the 122,670 migrant respondents, only $84.6 \%$ reported being economically active at the time of survey (Figure 1). Economically active refers to those individuals who are either employed or actively seeking employment at the time of survey, including both employed and unemployed. Employed refers to migrants who are currently working in a paid job. Among economically active migrants, 97.9\% were employed. There was a higher representation of females in the inactive and unemployed categories, while female migrants constituted about $41 \%$ of all employed individuals. Only employed migrants were asked questions about their monthly wages and working hours. Among the employed, 475 males and 333 females did not report either monthly wages or working hours. The difference in characteristics among the employed by wage reporting status was not statistically significant (data not shown separately). We excluded these 808 cases from the analysis. The final sample for the wage analysis constituted 100,771 employed (59,225 males and 41,546 females) internal labour migrants aged $16-59$. 
Figure 1: Flow chart showing the selection of study sample

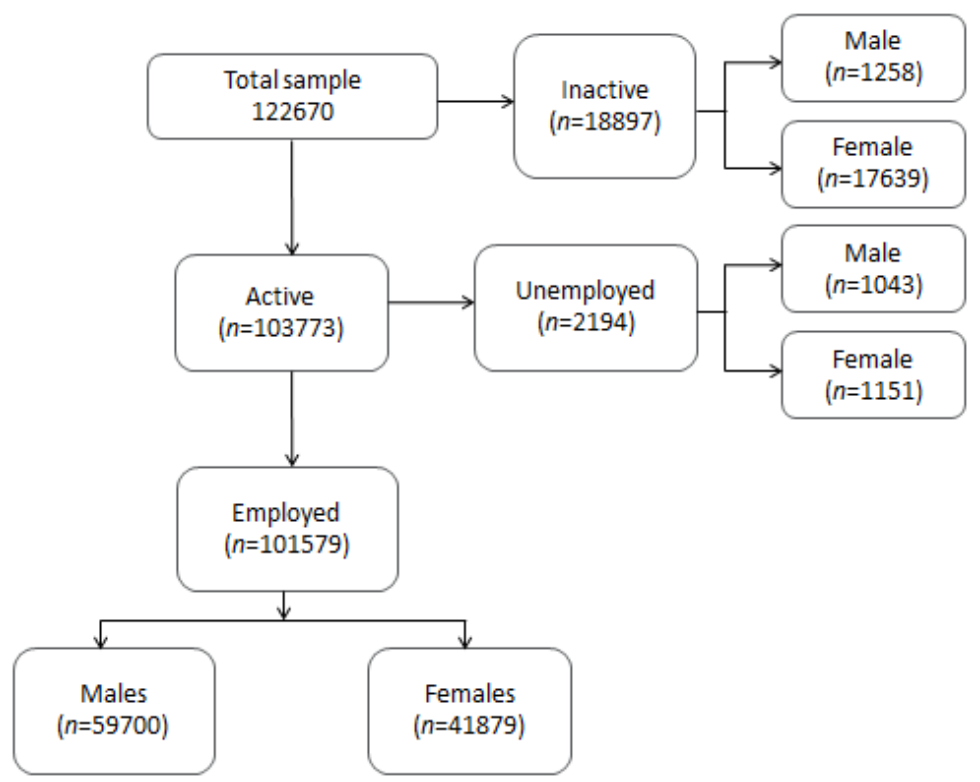

\section{Methodology}

The Heckman two-step Probit-OLS model was used to estimate a job participation equation and a wage-earning equation adjusting for relevant characteristics, separately for males and females. The dependent variable for the wage equation was logarithmic hourly wages, calculated as monthly wages divided by number of monthly hours based on reported hours worked per week (weekly hour×52/12). The conventional Mincerian earnings equation was deemed appropriate for empirical analysis of data from both high and middle income countries, including the Chinese context (Wang 2010; Magnani and Zhu 2012). The wage equation is given by:

$$
\ln \left(w_{j}\right)=\alpha+x_{j}^{\prime} \beta+\varepsilon_{j}
$$

where subscript $j$ denotes the individual, variable $w_{j}$ stands for hourly wages of individual $j, x_{j}$ is a column vector of explanatory variables for individual $j$, which includes education, training, experience, experience squared, gender and other 
geographic and occupational characteristics (Mincer 1974), and $\beta$ is the corresponding vector of model parameters.

Building on the concept of a Mincerian wage equation, a set of contextually relevant variables likely to be associated with job participation and wage-earning of migrants were identified based on evidence reported in previous studies (Duan, Zhang, and Lu 2010; Wang 2010; Magnani and Zhu 2012). The individual characteristics in the equation included human capital measured in terms of the highest grade of education; work experience measured in terms of the months in the current job, type of occupation, ownership of a company; age, marital status, ethnicity, rural/urban household registration of migrants; type of migration (inter-province and within province), length of time spent in the current location, type of accommodation, number of migrants in the household; region, city, number of migrants in the city, proportion of migrants in the city (number of migrants out of total usual residents), and whether the destination city is at the provincial, prefecture or county level. The identifying variable in the selection equation was age of the youngest child, which does not appear in the wage equation. This is justified by the fact that the presence of children can only impact wages through selection into employment (Heckman 1974, 1979; Mulligan and Rubinstein 2008).

Robust regression techniques were used, adjusting for clustering effects from the sample design, while the inclusion of design variables, for example, the number of migrants in the city, proportion of migrants and administrative level of the city were adjusted for the disproportionate sampling.

After testing and correcting for sample selection bias, the Blinder-Oaxaca decomposition of the male/female wage differential was applied to identify the reasons for male/female difference in mean wages. This technique divides the wage gap into a part that is explained by difference in predictors and a part that cannot be explained by group differences. Based on Jann (2008: 454), the wage difference can be written as $\mathrm{R}=\overline{\mathrm{W}}_{\mathrm{m}}-\overline{\mathrm{W}}_{\mathrm{f}}$, where $\overline{\mathrm{W}}_{\mathrm{m}}$ is the mean of the predicted log hourly wages of male migrants and $\bar{W}_{f}$ is the corresponding mean for female migrants. Then based on equation (1) applied separately for males and females, $\mathrm{R}$ can be expressed as:

$$
\begin{aligned}
\mathrm{R} & =\overline{\mathrm{w}}_{\mathrm{m}}-\overline{\mathrm{w}}_{\mathrm{f}}=\overline{\mathrm{x}}_{\mathrm{m}}^{\prime} \beta_{\mathrm{m}}-\overline{\mathrm{x}}_{\mathrm{f}}^{\prime} \beta_{\mathrm{f}} \\
& =\left[\overline{\mathrm{x}}_{\mathrm{m}}-\overline{\mathrm{x}}_{\mathrm{f}}\right]^{\prime} \beta_{\mathrm{f}}+\overline{\mathrm{x}}_{\mathrm{f}}^{\prime}\left(\beta_{\mathrm{m}}-\beta_{\mathrm{f}}\right)+\left[\overline{\mathrm{x}}_{\mathrm{m}}-\overline{\mathrm{x}}_{\mathrm{f}}\right]^{\prime}\left(\beta_{\mathrm{m}}-\beta_{\mathrm{f}}\right)
\end{aligned}
$$

The first component $\left[\bar{x}_{m}-\bar{x}_{f}\right] \beta_{f}$ is the 'endowments effect', the differential due to group differences in the mean of the predictors given by $\overline{\mathrm{x}}_{\mathrm{m}}$ and $\overline{\mathrm{x}}_{\mathrm{f}}$. The second component $\bar{x}_{\mathrm{f}}^{\prime}\left(\beta_{\mathrm{m}}-\beta_{\mathrm{f}}\right)$ measures the contribution of differences in the coefficients 
(including intercept). The third component $\left[\overline{\mathrm{x}}_{\mathrm{m}}-\overline{\mathrm{x}}_{\mathrm{f}}\right]^{\prime}\left(\beta_{\mathrm{m}}-\beta_{\mathrm{f}}\right)$ is an interaction term accounting for the fact that differences in endowments and coefficients exist simultaneously between the two groups. The substantial part of $\bar{x}_{\mathrm{f}}^{\prime}\left(\beta_{\mathrm{m}}-\beta_{\mathrm{f}}\right)$ is commonly attributed to gender discrimination, although it might reflect the omission of important variables from X (Su and Heshmati 2011).

\section{Results}

\subsection{Descriptive}

The demographic and social characteristics of male and female internal labour migrants are presented in Table 1 . About $77 \%$ of the respondents are married, and more than $85 \%$ have rural household registration at their place of origin. More than $80 \%$ of internal labour migrants have completed middle school, but only just over $30 \%$ completed high school or above. Female migrants have slightly lower levels of education than male migrants. Inter-province migrants account for more than $70 \%$ of the study sample. The average age of migrants is 32 years, which does not differ between males and females, with a standard deviation of about 9 years (results not shown separately).

For the internal labour migrants, $97.2 \%$ males and $77.4 \%$ females are employed in paid work. Figure 2 shows that job participation for male internal labour migrants is stable and high across all ages, while for females it starts with the highest proportion in the youngest age group, then drops down around ages $25-34$, followed by a recovery by ages 35-49, and then declines dramatically after age 50. Generally, females exit jobs at peak reproductive ages, have children, and then usually return to their jobs as their children get older. Most migrants live in the eastern region (86.8\%). About 82\% live in neighbourhood community households and the rest live in factory dormitories. One in four migrants have been living in their destination for over 7 years and about one in five lives in cities where more than $50 \%$ of the population are migrants. About $20 \%$ of migrants have young children below 6 years and about $69 \%$ live in households with two or more internal labour migrants. 
Qin et al.: Gender inequalities in employment and wage-earning among internal labour migrants

Table 1: Percentage distribution of male and female internal labour migrants by demographic and social characteristics $(n=121,862)$

\begin{tabular}{|c|c|c|c|}
\hline Variable & Male & Female & Total \\
\hline \multicolumn{4}{|l|}{ Marital status } \\
\hline Married & 75.9 & 77.8 & 76.9 \\
\hline Unmarried & 24.1 & 22.2 & 23.1 \\
\hline \multicolumn{4}{|c|}{ Household registration (hukou status) } \\
\hline Rural & 86.4 & 86.5 & 86.4 \\
\hline Urban & 13.6 & 13.5 & 13.6 \\
\hline \multicolumn{4}{|l|}{ Ethnicity } \\
\hline Han & 95.2 & 95.4 & 95.3 \\
\hline Non-han & 4.8 & 4.6 & 4.7 \\
\hline \multicolumn{4}{|l|}{ Education } \\
\hline Primary & 12.0 & 19.7 & 16.0 \\
\hline Middle & 55.3 & 52.6 & 53.9 \\
\hline High school and above & 32.6 & 27.7 & 30.1 \\
\hline \multicolumn{4}{|l|}{ Job participation } \\
\hline Yes & 97.2 & 77.4 & 87.0 \\
\hline No & 2.8 & 22.6 & 13.0 \\
\hline \multicolumn{4}{|l|}{ Migration type } \\
\hline Inter-province & 72.5 & 71.5 & 72.0 \\
\hline Within province & 27.5 & 28.5 & 28.5 \\
\hline \multicolumn{4}{|l|}{ Region of destination } \\
\hline East & 86.3 & 87.3 & 86.8 \\
\hline Central & 4.6 & 4.7 & 4.7 \\
\hline West & 9.1 & 8.0 & 8.5 \\
\hline \multicolumn{4}{|l|}{ Type of accommodation } \\
\hline Community & 83.3 & 82.1 & 82.7 \\
\hline Factory dormitory & 16.7 & 17.9 & 17.3 \\
\hline \multicolumn{4}{|l|}{ Duration lived in the destination } \\
\hline $0-12$ months & 21.8 & 22.7 & 22.2 \\
\hline 13-36months & 25.4 & 27.8 & 26.6 \\
\hline 37-84months & 26.6 & 27.3 & 26.9 \\
\hline >84months & 26.2 & 22.3 & 24.2 \\
\hline \multicolumn{4}{|l|}{$\%$ share of migrants in the city } \\
\hline$<25$ & 34.0 & 30.7 & 32.3 \\
\hline $25-49.99$ & 47.9 & 49.8 & 48.9 \\
\hline 50 or more & 18.0 & 48.9 & 18.8 \\
\hline \multicolumn{4}{|l|}{ Age of youngest child (in years) } \\
\hline $0-5$ & 19.1 & 21.0 & 20.1 \\
\hline $6-17$ & 15.2 & 16.2 & 15.7 \\
\hline 18 and above or no children & 65.7 & 62.8 & 64.2 \\
\hline \multicolumn{4}{|c|}{ No. of internal labour migrants in the household } \\
\hline 1 & 33.7 & 28.9 & 31.2 \\
\hline 2 or more & 66.3 & 71.1 & 68.8 \\
\hline
\end{tabular}

Note: the percentages shown are based on weighted data. 
Figure 2: Job-participation by gender and age group among internal labour migrants in Chinese cities

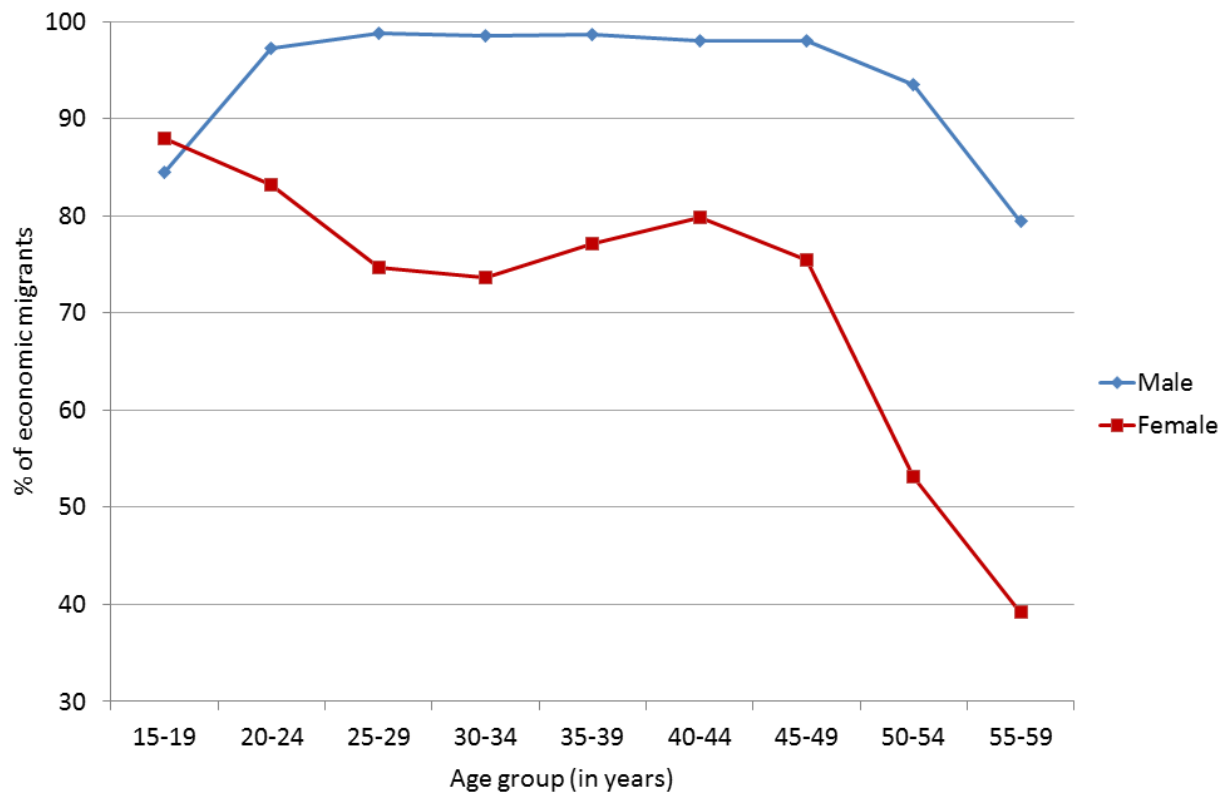

The occupational characteristics of migrants are shown in Table 2. About $37 \%$ of male and female migrants work in the manufacturing sectors. However, male migrants are twice as likely as females to be in professional jobs such as managers or professional technicians. About $74 \%$ of male and female migrants are employed in private companies; for females (15.3\%) there is a greater proportion in foreign investment companies than males (10\%). Overall, about $24 \%$ of migrants are selfemployed, less than $4 \%$ are employers and the rest work as employees. The average years spent in their current employment is higher for males (44.3 months) than females (37.6). The average income is higher among males (2840 Chinese Renminbi (RMB)) than females (2229 RMB) and females earn on average 2 RMB less per hour than their male counterparts. Figure A-1 (see Appendix A) shows the histogram illustrating the normal distribution of log hourly wages for both male and female migrants. Once we control for the level of education, female earnings remain slightly less than male; while as the level of education increases, the hourly wages increase for both male and female migrants (Figure 3). 
Qin et al.: Gender inequalities in employment and wage-earning among internal labour migrants

\section{Table 2: Occupational characteristics of male and female internal labour migrants $(n=100,771)$}

\begin{tabular}{|c|c|c|c|}
\hline Variable & Male & Female & Total \\
\hline \multicolumn{4}{|l|}{ Occupation } \\
\hline Professional & 16.6 & 8.2 & 12.7 \\
\hline Clerical & 3.8 & 5.4 & 4.5 \\
\hline Small business & 14.2 & 14.9 & 14.5 \\
\hline Social service providers & 22.7 & 29.4 & 25.8 \\
\hline Manufacturing workers & 36.6 & 37.6 & 37.1 \\
\hline Agriculture workers & 1.1 & 1.1 & 1.1 \\
\hline No fixed job & 5.0 & 3.3 & 4.2 \\
\hline \multicolumn{4}{|l|}{ Ownership of the company } \\
\hline State-owned & 5.4 & 3.7 & 4.6 \\
\hline Collective & 2.4 & 2.0 & 2.2 \\
\hline Private & 74.0 & 73.7 & 73.9 \\
\hline Foreign investment & 10.0 & 15.3 & 12.5 \\
\hline Others & 8.2 & 5.3 & 6.9 \\
\hline \multicolumn{4}{|l|}{ Employment status } \\
\hline Employee & 68.7 & 75.3 & 71.7 \\
\hline Self-employed & 27.0 & 21.6 & 24.5 \\
\hline Employer & 4.2 & 3.1 & 3.7 \\
\hline \multicolumn{4}{|l|}{ Training attendance } \\
\hline Yes & 18.2 & 17.4 & 17.8 \\
\hline No & 81.8 & 82.6 & 82.2 \\
\hline Months spent in current job & 44.3 & 37.6 & 41.2 \\
\hline \multicolumn{4}{|l|}{ Monthly wages } \\
\hline (in Chinese Renminbi RMB) & 2840 & 2229 & 2560 \\
\hline Hourly wages (RMB) & 9 & 7 & 8 \\
\hline
\end{tabular}

Note: the percentages shown are based on weighted data. 
Figure 3: Mean logarithmic hourly wages among employed migrants by gender and education

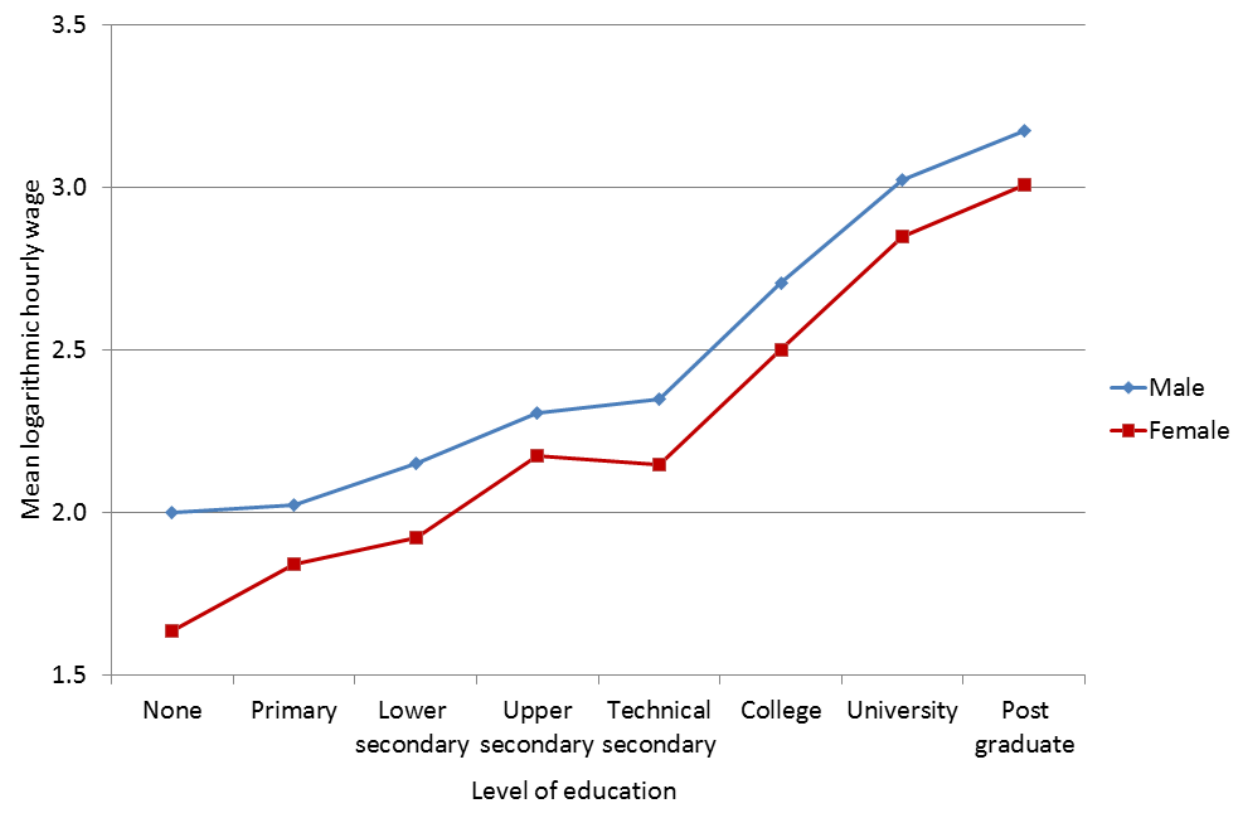

\subsection{Probit regression analysis}

Table 3 presents the estimates from the probit selection model for labour force participation. The results are informative in understanding the characteristics of male and female migrants engaged in paid employment. We report both the coefficient and the average marginal effect of the independent variables. The marginal effect is the expected change in the average probability of the outcome $p(\mathrm{Y}=1)$, if the independent variable changes by one unit, holding all the other variables constant. 
Qin et al.: Gender inequalities in employment and wage-earning among internal labour migrants

Table 3: $\quad$ Estimates of the job participation equation from robust probit regression

\begin{tabular}{|c|c|c|c|c|}
\hline \multirow{2}{*}{ Variables } & \multirow{2}{*}{$\frac{\text { Male }}{\text { Marginal effect }}$} & \multicolumn{3}{|c|}{ Female } \\
\hline & & Coefficient & Marginal effect & Coefficient \\
\hline Age & $-0.0004(0.000)^{\star \star}$ & $-0.0065^{\star \star}$ & 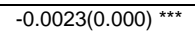 & $-0.0080^{\star \star \star}$ \\
\hline Han ethnicity (ref: non-han) & $-0.0009(0.003)$ & -0.0133 & $0.0144(0.010)$ & 0.0513 \\
\hline Married (ref: unmarried) & $0.0665(0.004)^{\star \star \star}$ & $1.0124^{\star \star \star}$ & $0.0023(0.011)$ & 0.0081 \\
\hline Rural household registration (ref: urban) & $0.0197(0.002)^{\star \star \star}$ & $0.3001^{\star \star \star}$ & $-0.0014(0.007)$ & -0.0049 \\
\hline Middle school (ref: primary) & $0.0164(0.003)^{\star \star \star}$ & $0.2500^{\star \star \star}$ & $0.0431(0.005) * \star \star$ & $0.1533^{\star \star \star}$ \\
\hline High school (ref: primary) & $0.0036(0.003)$ & 0.0551 & $0.0633(0.007) * \star \star$ & $0.2251^{\star \star \star}$ \\
\hline Inter-province migration (ref: within province) & $0.0134(0.002)^{\star \star \star}$ & $0.2043^{\star \star \star}$ & $0.0333(0.005) * \star \star$ & $0.1182^{\star \star \star}$ \\
\hline $\begin{array}{l}\text { Duration lived in the destination } 13-36 \text { months } \\
\text { (ref: } 0-12 \text { months) }\end{array}$ & $-0.0002(0.003)$ & -0.0033 & $0.0202(0.006) * \star \star$ & $0.0716^{\star \star \star}$ \\
\hline $\begin{array}{l}\text { Duration lived in the destination } 37-84 \text { months } \\
\text { (ref: } 0-12 \text { months) }\end{array}$ & $0.0014(0.003)$ & 0.0217 & 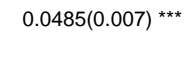 & $0.1722^{\star \star \star}$ \\
\hline $\begin{array}{l}\text { Duration lived in the destination }>84 \text { months } \\
\text { (ref: } 0-12 \text { months) }\end{array}$ & $-0.0068(0.003)^{*}$ & $-0.1036^{*}$ & 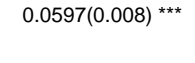 & 0.2120 *** \\
\hline Age of youngest child $0-5$ (ref: $>18$ or no children) & $0.0190(0.003)^{\star \star \star}$ & $0.2884^{\star \star \star}$ & $-0.2047(0.006)^{\star \star \star}$ & $-0.7272^{\star \star \star}$ \\
\hline Age of youngest child $6-17$ (ref: $>18$ or no children) & $0.0230(0.002)^{\star \star \star}$ & $0.3498^{\star \star \star}$ & $-0.0201(0.006) * \star \star$ & $-0.0715^{\star \star \star}$ \\
\hline 2 economic migrants in the household (ref: 1 migrant) & $-0.0463(0.004)^{\star \star \star}$ & $-0.7046^{\star \star \star}$ & $-0.2749(0.010) \star \star \star$ & $-0.9768^{\star \star \star}$ \\
\hline$>2$ economic migrants in the household (ref: 1 migrant) & $-0.0778(0.003)^{\star \star \star}$ & $-1.1834^{\star \star \star}$ & $-0.3187(0.010) * \star \star$ & $-1.1324^{\star \star \star}$ \\
\hline Living in community household (ref: factory dormitory) & $-0.0013(0.004)$ & -0.0197 & $-0.0107(0.010)$ & -0.0382 \\
\hline East region (ref: West) & $0.0302(0.040)$ & 0.4590 & $0.1777(0.215)$ & 0.6314 \\
\hline Central region (ref: West) & $0.0403(0.017)^{\star}$ & $0.6125^{\star}$ & $0.2882(0.110)^{\star \star}$ & $1.0239^{\star \star}$ \\
\hline Number of migrants in the city (per 100,000$)$ & $-0.0022(0.006)$ & -0.0330 & $-0.0260(0.030)$ & -0.0925 \\
\hline Proportion of migrants in the city & $0.0001(0.001)$ & 0.0013 & $0.0016(0.008)$ & 0.0056 \\
\hline Prefecture level city (ref: provincial level) & $-0.0164(0.010)$ & -0.2499 & 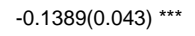 & $-0.4936^{\star \star \star}$ \\
\hline County level city (ref: provincial level) & $-0.0524(0.035)$ & -0.7978 & 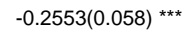 & $-0.9070^{\star \star \star}$ \\
\hline Constant & & $1.3162^{\star \star \star}$ & & $1.4392^{\star \star \star}$ \\
\hline
\end{tabular}

Note: ${ }^{\star} p<0.05,{ }^{\star \star} p<0.01,{ }^{\star \star \star} p<0.001$. City dummies are controlled for in the regression (effects not shown separately). 
The results show that age of the youngest child, a key variable in determining the probability of a person being employed as well as the identification of the two-step regression, has a contradicting effect on job participation for male and female migrant models. Having the youngest child aged $0-5$ or aged 6-17 increases the probability of a male migrant being employed compared to those with the youngest child older than 18 or those with no children. For female migrants, the effect of this variable is opposite. Having the youngest child aged $0-5$ or $6-17$ reduces the probability of a woman being employed.

Education is another key variable in male-female employment participation differences. For male migrants, compared to those with primary school education, the probability of being employed increases for those with middle school education. Interestingly, high school and above education has no significant effect on the employment of males relative to their counterparts with primary education. Whereas for female migrants, compared to the primary school education, the probability of being employed increases for middle school and high school and above education. This suggests that the more educated female migrants are likely to seek or have better employment opportunities than their lower educated counterparts, but for male migrants education plays a less important role.

After controlling for city effects, number of migrants in the city and proportion of migrants in the city have no significant effect on job participation for both male and female. The effects of these two factors, if any, are likely to be picked up by city fixed effects. The opportunities for a paid job for female migrants are less in the prefecture and county level cities when compared to those in the provincial level cities.

\subsection{Evidence of sample selection effects}

Table 4 presents the estimates of the wage equation, before and after correcting for sample selection. The coefficient of Lambda $^{7}$ is significant and negative for male migrants $(-0,131)$ while for female migrants it is positive but not significant. This indicates the presence of sample selection bias and the need for correction for the male migrant models. Lambda can be interpreted as the covariance between the error terms in the job participation and wage functions, and its sign implies the mechanism of the selection into waged employment that is working (Nicaise 2001). The negative $\lambda$ means the characteristics that increase an individual's salary are those that decrease the

\footnotetext{
${ }^{7}$ Lambda is the inverse of Mill's ratio (Jann 2008) - the probability density function over the cumulative function of a distribution. The inverse Mills ratio in Heckman's two-stage model is used to adjust the second stage of the wage regression for the first selection stage, as if the sample were randomly selected.
} 
Qin et al.: Gender inequalities in employment and wage-earning among internal labour migrants

probability of being employed. While the positive $\lambda$ indicates the characteristics either increase or decrease both the wages and probability of being employed.

\section{Table 4: Coefficient estimates of the wage equation with log wages as the dependent variable, without correction (OLS) and with correction (Heckman)}

\begin{tabular}{|c|c|c|c|c|}
\hline \multirow{2}{*}{ Variables } & \multirow{2}{*}{ OLS } & \multicolumn{3}{|c|}{ Heckman } \\
\hline & & Female & Male & Female \\
\hline Age (in years) & $0.037(0.002)^{\star \star \star}$ & 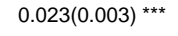 & 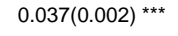 & $0.023(0.003) * \star \star$ \\
\hline Age (in years, squared) & $-0.001(0.000)^{\star \star \star}$ & $0.000(0.000) \star \star \star ~$ & $-0.001(0.000) * \star \star$ & $0.000(0.000) * \star *$ \\
\hline Han ethnicity (ref: non-Han) & $0.076(0.015)^{\star \star \star}$ & $0.042(0.017)$ * & 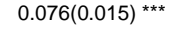 & $0.042(0.017) *$ \\
\hline Married (ref: unmarried) & $0.160(0.011)^{\star \star \star}$ & $0.029(0.013)$ * & 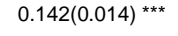 & $0.028(0.013) *$ \\
\hline Rural household registration (ref: urban) & $-0.022(0.054)$ & 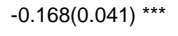 & $-0.031(0.054)$ & $-0.168(0.041)^{\star \star \star}$ \\
\hline Middle school (ref: primary) & $0.092(0.055)$ & $-0.012(0.041)$ & $0.085(0.055)$ & $-0.009(0.041)$ \\
\hline High school (ref: primary) & $0.260(0.055)^{\star \star \star}$ & $0.159(0.041) \star \star \star ~$ & 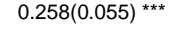 & $0.162(0.041) * \star \star$ \\
\hline Inter-province migration (ref: within province) & $0.055(0.008)^{\star \star \star}$ & 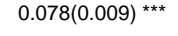 & 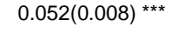 & $0.079(0.009) * \star \star$ \\
\hline $\begin{array}{l}\text { Duration lived in the destination } 13-36 \text { months } \\
\text { (ref: } 0-12 \text { months) }\end{array}$ & $0.017(0.009)$ & $-0.007(0.009)$ & $0.018(0.009)$ & $-0.007(0.009)$ \\
\hline $\begin{array}{l}\text { Duration lived in the destination } 37-84 \text { months } \\
\text { (ref: } 0-12 \text { months) }\end{array}$ & $-0.003(0.011)$ & 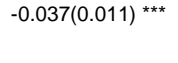 & $-0.002(0.011)$ & $-0.036(0.011) * *$ \\
\hline $\begin{array}{l}\text { Duration lived in the destination }>84 \text { months } \\
\text { (ref: } 0-12 \text { months) }\end{array}$ & $-0.036(0.013)^{\star \star}$ & 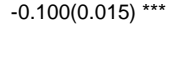 & $-0.033(0.013)^{\star \star}$ & $-0.098(0.015) * * \star$ \\
\hline $\begin{array}{l}2 \text { economic migrants in the household (ref: } 1 \\
\text { migrant) }\end{array}$ & $-0.020(0.011)$ & $-0.033(0.011) * \star$ & $-0.012(0.011)$ & $-0.043(0.015) * \star$ \\
\hline $\begin{array}{l}>2 \text { economic migrants in the household ( } 1 \\
\text { migrant) }\end{array}$ & $-0.012(0.012)$ & $-0.045(0.014) * \star$ & $0.009(0.016)$ & 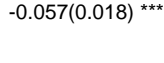 \\
\hline $\begin{array}{l}\text { Living in the community household (ref: factory } \\
\text { dormitory) }\end{array}$ & $0.013(0.015)$ & $0.009(0.015)$ & $0.015(0.015)$ & $0.009(0.015)$ \\
\hline Months spent in the current job & $0.001(0.000)^{\star \star \star}$ & 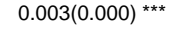 & 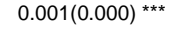 & $0.002(0.000) * \star \star$ \\
\hline Months spent in the current job (squared) & $0.000(0.000)^{\star \star \star}$ & 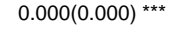 & 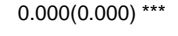 & $0.000(0.000) * \star \star$ \\
\hline Attended work training (ref: not attended) & $0.074(0.011)^{\star \star \star}$ & 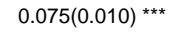 & 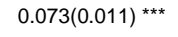 & $0.075(0.010) * \star \star$ \\
\hline Self-employed (ref: employee) & $0.188(0.014)^{\star \star \star}$ & 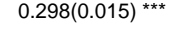 & 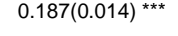 & 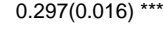 \\
\hline Employer (ref: employee) & $0.514(0.022)^{\star \star \star}$ & 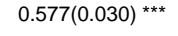 & 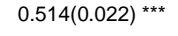 & $0.578(0.030)^{\star \star \star}$ \\
\hline Clerical (ref: professional) & $-0.002(0.016)$ & $0.001(0.025)$ & $-0.002(0.016)$ & $-0.001(0.025)$ \\
\hline
\end{tabular}


Table 4: $\quad$ (Continued)

\begin{tabular}{|c|c|c|c|c|}
\hline \multirow{2}{*}{ Variables } & \multirow{2}{*}{$\frac{\text { OLS }}{\text { Male }}$} & \multicolumn{3}{|c|}{ Heckman } \\
\hline & & Female & Male & Female \\
\hline Business (ref: professional) & $-0.109(0.016)^{\star \star \star}$ & $-0.085(0.019) \star \star \star$ & $-0.108(0.016) * \star \star$ & 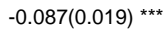 \\
\hline Service provider (ref: professional) & $-0.211(0.011)^{\star \star \star}$ & $-0.192(0.016) * \star \star$ & $-0.211(0.011) * \star \star$ & $-0.194(0.016) * \star \star$ \\
\hline Agriculture (ref: professional) & $-0.284(0.043)^{\star \star \star}$ & $-0.249(0.048) \star \star \star$ & $-0.284(0.043) * * \star$ & 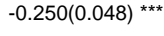 \\
\hline Manufacturing (ref: professional) & $-0.128(0.011)^{\star \star \star}$ & 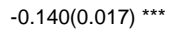 & 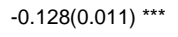 & 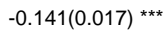 \\
\hline No fixed job (ref: professional) & $-0.246(0.016)^{\star \star \star}$ & 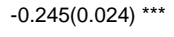 & $-0.246(0.016) * \star \star$ & $-0.247(0.025) * \star \star$ \\
\hline Collective (ref: state-owned) & $-0.079(0.028)^{\star \star}$ & $-0.021(0.027)$ & $-0.080(0.028) * *$ & $-0.020(0.027)$ \\
\hline Private (ref: state-owned) & $-0.077(0.021)^{\star \star \star}$ & $-0.047(0.019)^{\star}$ & $-0.078(0.021) * \star \star$ & $-0.046(0.019)^{\star}$ \\
\hline Foreign (ref: state-owned) & $-0.060(0.025)^{\star}$ & $0.030(0.023)$ & $-0.060(0.025) *$ & $0.031(0.023)$ \\
\hline Other (ref: state-owned) & $-0.162(0.026)^{\star \star \star}$ & $-0.169(0.028) \star \star \star ~$ & 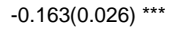 & 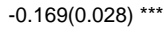 \\
\hline Working hours & $-0.015(0.000)^{\star \star \star}$ & $-0.013(0.000) \star \star \star ~$ & $-0.015(0.000) * \star \star$ & 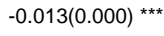 \\
\hline East region (ref: West) & $0.040(0.213)$ & $-0.293(0.044) * \star \star$ & $0.018(0.213)$ & $-0.282(0.046) * \star \star$ \\
\hline Central region (ref: West) & $-0.021(0.133)$ & $-0.381(0.123) * \star$ & $0.045(0.200)$ & $-0.391(0.124) \star \star$ \\
\hline No. of migrants in the city (per 100,000 ) & $0.001(0.002)$ & 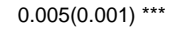 & $0.001(0.002)$ & $0.004(0.001) * \star \star$ \\
\hline Proportion of migrants in the city & $0.003(0.004)$ & $0.003(0.001) *$ & $0.003(0.004)$ & $0.003(0.001) \star \star$ \\
\hline Prefecture level city (ref: Provincial level) & $0.065(0.165)$ & $0.259(0.106)$ * & $0.012(0.210)$ & $0.237(0.108)$ * \\
\hline County level city (Provincial level ref.) & $-0.096(0.141)$ & $0.306(0.049) * \star \star$ & $-0.072(0.141)$ & 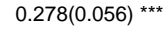 \\
\hline Rural household registration*Middle school & $-0.009(0.055)$ & $0.100(0.043)$ * & $-0.004(0.055)$ & $0.099(0.043)$ * \\
\hline Rural household registration*High school & $-0.116(0.055)^{*}$ & $0.032(0.043)$ & $-0.114(0.055)^{\star}$ & $0.032(0.043)$ \\
\hline Constant & $2.114(0.089)^{\star \star \star}$ & $2.154(0.086)^{\star \star \star}$ & $2.145(0.090)^{\star \star \star}$ & $2.147(0.086)^{\star \star \star}$ \\
\hline No. of observations & 59225 & 41546 & 58907 & 41480 \\
\hline $\mathrm{R}^{2}$ & 0.224 & 0.213 & 0.223 & 0.213 \\
\hline$F$ & 69.88 & 48.68 & 70.04 & 49.26 \\
\hline Lambda & & & $-0.131(0.054)^{*}$ & $0.027(0.026)$ \\
\hline
\end{tabular}

Note: ${ }^{\star} p<0.05,{ }^{\star \star} p<0.01,{ }^{\star \star \star} p<0.001$. City dummies are controlled for in the regression (effects not shown separately). 


\subsection{OLS results after the adjustment of sample selection}

After the adjustment for sample selection bias, the OLS results indicate that the individual's wage determination process is influenced by all the human capital variables for both male and female migrants. Training and experience effects are in the expected direction. Highly trained individuals with skills and experience seem to be rewarded with higher wages. Although both the squared term and linear term for experience are positive, suggesting increasing rewards for increasing experience, the size of the coefficients is small. We found that rural hukou status has a negative effect on wageearning for both male and female migrants. In order to examine whether increase in education would change the disadvantage of rural hukou status, we have included an interaction term of education and hukou status in the model.

The results show (Table 4) that the interaction term of high school and rural hukou for male migrants and interaction term of middle school and rural hukou for female migrants have significant effect on wages. The coefficient -0.114 for the interaction between high school and rural hukou indicates that high school has a generally positive effect on wages; the effect is much smaller for rural hukou male migrants than for urban hukou. The coefficient 0.099 indicates that middle education has no significant effect for urban hukou female migrants; but a significant negative effect on wages for rural hukou female migrants. Therefore, it appears that education does not reduce the rural hukou migrant disadvantage for either males or females. Further explanations are provided in Appendix B. The results from Table 4 also show that occupation, ownership of a company, and employment status are all determinants of migrant wages.

\subsection{Decomposition results}

Table 5 reports the results from decomposition, with and without sample selection correction, for male and female migrants. The results show that the difference in coefficient effect increases from 0.235 to 0.244 after correcting for sample selection bias. Considering the decomposition analysis, the endowments account for $4.6 \%$ $(0.011 / 0.244)$ and the coefficients account for $88.1 \%(0.215 / 0.244)$. The interaction accounts for the residual $7.2 \%(0.018 / 0.244)$. Therefore, the average wages for female migrants in the population would increase by $4.6 \%$ if they had the same characteristics as males. However, the change in the average wages for female migrants would be $11.8 \%(0.215 / 1.828)$ if the males' coefficients are applied to the females' characteristics. This is strongly indicative of discrimination in the labour market against female migrants, although it may also suggest that other unobserved effects are present (addressed in the next section). 
Table 5: Results from the Blinder-Oaxaca decomposition

\begin{tabular}{lcc}
\hline Log (wage) & $\begin{array}{c}\text { Uncorrected } \\
\text { coefficient }\end{array}$ & $\begin{array}{c}\text { Corrected } \\
\text { coefficient }\end{array}$ \\
\hline Differential effect & $2.064(0.003)^{\star \star \star}$ & $2.064(0.003)^{\star \star \star}$ \\
Prediction for male & $1.828(0.003)^{\star \star \star}$ & $1.828(0.011)^{\star \star \star}$ \\
Prediction for female & $0.235(0.005)^{\star \star \star}$ & $0.235(0.005)^{\star \star \star}$ \\
Difference & & $0.244(0.011)^{\star \star \star}$ \\
Adjusted & & \\
Decomposition effect & & \\
Endowments & $0.011(0.003)^{\star \star \star}$ & $0.011(0.003)^{\star \star \star}$ \\
Coefficients & $0.206(0.004)^{\star \star \star}$ & $0.215(0.006)^{\star \star \star}$ \\
Interaction & $0.018(0.003)^{\star \star \star}$ & $0.018(0.003)^{\star \star \star}$ \\
\hline
\end{tabular}

Note: ${ }^{\star} \mathrm{p}<0.05,{ }^{\star \star} \mathrm{p}<0.01,{ }^{\star \star \star} \mathrm{p}<0.001$.

\section{Discussion}

The foregoing analysis based on a national survey demonstrates significant inequality between female migrants and their male counterparts in the job market in Chinese cities. The results highlight the differences in the way in which female migrants have adjusted to the migration process compared to male migrants. Female migrants have much lower job participation and lower wage-earning than male migrants. Female migrants in cities are often subject to dual pressure to leave employment and resume the role of full-time homemaker or mother, and then subsequently to return to employment due to economic pressure in households. This suggests that those with young children are less likely to be active in employment. The present findings at the national level are consistent with the evidence from other qualitative research and small-scale surveys in specific cities (Ye, Ge, and Ye 2005; Fan 2004; Fan 2003). Results from a poll conducted in Jiansu province showed that $80 \%$ of female respondents felt they had experienced discrimination in recruitment and that employers had been explicit in stating their preference for men, even with bold phrases in their advertisements such as 'male graduates only' (Chao 2003). These discriminatory practices apply not only in private companies but also in government departments, state-owned enterprises and foreign invested companies. Often the recruited women were issued with (illegal) contracts stating 'no birth for five years' (Chao 2003). We found that migrants with 
rural hukou status face disadvantages in job participation and wage-earning in urban cities, regardless of any education difference. The household registration system remains a barrier for migrants in the labour market.

The decomposition results of the wage difference between males and females confirm evidence of potential gender discrimination, suggesting that $88 \%$ of the gender gap in wages (or $12 \%$ of female migrant wages) is attributed to different treatment of female migrants in the Chinese job market. As observed elsewhere, in other East Asian countries, widespread discrimination of women at work exists in Chinese cities for reasons related to their reproductive and childcare responsibilities. Another reason is the stereotyped gender-biased attitudes among labour market actors in terms of the types of jobs differentiated by gender and preferences for either young women or men in specific sectors. The discriminatory attitudes and practices in the job recruitment and employment sectors have left women with little choice but to take up jobs in lower levels of different sectors not protected by labour legislation (ILO 2008).

In recent decades, the large influx of migrant labourers in China has been crucial to the urban economic growth, especially for the construction and service sectors, and foreign-invested factories. The remittances sent back to the countryside and returning migrants taking back their savings, new skills and social connections have been important for rural families and rural development (Tuñón 2006). However, labour migrants draw on and reinforce various overlapping socio-economic segregations, such as rural and urban, male and female, educated and uneducated; through the exclusion of rural people from urban health, education, housing and social security systems. Even the welfare system linked to employment status, introduced in the 1950s, by its design had institutionalised inequalities. In 2003, the central government endorsed actions to remove unfair restrictions on labour migrants and promoted equal treatment for migrants in employment. However, these efforts seem to have had little effect.

The major divide or discrimination lies between rural and urban hukou residence, with the rural being consistently underprivileged compared to the urban. Even within urban China, the welfare system is fragmented, as those in government sectors and state-owned enterprises enjoy benefits and support that are not available to those working in other sectors of the economy, especially in the informal sector mostly represented by migrant labours. Urban-biased social economic policy particularly around the social welfare system, affects the flexibility of the labour market. The consequence is that internal migrants generally take the jobs that urban residents would not consider.

The evidence of gender inequality in employment and wages among internal labour migrants reported in this study is just one aspect of the social inequities in contemporary China. Without changes in the government's long-standing development policies, for instance, detaching social services and welfare benefits from hukou status 
and integrating the fragmented welfare systems, it is unlikely that such inequalities can be effectively eliminated.

The findings reported in this study address the recently introduced Target 8.8 of the United Nations Sustainable Development Goals, which stress the importance of protecting labour rights, especially for migrant women (United Nations 2015). The results of our analysis will be useful in formulating gender-equitable public policies for addressing urban unemployment among male and female migrants. Economic policies and social interventions should aim to close the gender division in labour participation by setting minimum wage standards to ensure equity, and by allowing flexibility for females to balance their work and family life. Given the large flow of both skilled and unskilled migration from rural areas to big cities, the Chinese government has multiple challenges in creating employment opportunities and welfare measures for migrants and their families. The critical challenge is to address the social and economic implications of the feminisation of migration in China and the competing needs of female internal labour migrants, in terms of child care and social services for better work/life balance.

The present study contributes to the unravelling of the gender inequalities and heterogeneity in job participation and wage-earning, focusing on a nationally representative sample of migrants living in Chinese cities. However, given the data constraints, it does not address the issue of discrimination against migrants in favor of non-migrants or indeed, changes across time at the individual level. Future research should consider using panel data comparing migrants and non-migrants to examine such influences.

\section{Acknowledgements}

This research was conducted as part of the UK Economic \& Social Research Council (ESRC) China-South Africa Pathfinder Collaborative Analysis of Microdata Resources project entitled 'Gender Disadvantage, Social Inequalities and Wellbeing of Internal labour migrants in China'. The authors gratefully acknowledge the ESRC for funding (Grant reference: ES/I035184/1), and the National Population and Family Planning Commission and the China Population and Development Research Centre for providing access to the 2010 Migrant Dynamics Monitoring Survey data. 
Qin et al.: Gender inequalities in employment and wage-earning among internal labour migrants

\section{References}

All-China Women's Federation (ACWF) (2006). Report on the Social Status of Women in China: Economy. Beijing: All China Women's Federation (in Chinese). http://www.womenofchina.cn/womenofchina/html1/7/6991-1.htm.

Bishop, J., Luo, F., and Wang, F. (2005). Economic transition, gender bias, and the distribution of earnings in China. Economics of Transition 13(2): 239-259. doi:10.1111/j.1468-0351.2005.00218.x.

Brainerd, E. (2000). Women in Transition: Changes in Gender Wage Differentials in Eastern Europe and the Former Soviet Union. Industrial and Labor Relations Review 54(1): 138-162. doi:10.2307/2696036.

Cai, F. (2011). Population, employment and income allocation. In: Cai, F. (ed.). Reports on Chinese population and growth. Beijing: Social Science Academic Press (in Chinese).

Cai, F. (2004). Demographic transition, demographic dividend and sustainability of economic growth: maximum employment as a source of economic growth. Population Research 28(2): 36-47 (in Chinese).

Cai, F., Lin, J.Y., and Cao, Y. (2009). The Chinese economy: Reform and development. McGraw-Hill Publishers.

Chao, C. (2003). Gender gap, discrimination for women university graduates (in Chinese). http://www1.china.org.cn/english/2003/Apr/62907.htm.

Chiang, Y.L., Hannum, E.C., and Kao, G. (2013) It's not just about the money: Motivations for youth migration in rural China. Asia-Pacific Education, Language Minorities and Migration (ELMM) Network Working Paper Series. Population Studies Center. http://repository.upenn.edu/cgi/viewcontent. cgi?article $=1005 \&$ context $=$ elmm.

Davin, D. (2005). Women and migration in contemporary China. China Report 41(1): 29-38. doi:10.1177/000944550504100102.

Du, Y. and Pan, W.G. (2009). Minimum wage regulation in China and its application to migrant workers in the urban labour market. China and World Economy 17(2): 79-93. doi:10.1111/j.1749-124X.2009.01143.x.

Duan, C.R., Zhang, F., and Lu, X.H. (2010). Factors influencing the income of Chinese female migrant labor force. Collection of Women's Studies 4(100): 29-34 (in Chinese). 
Eklund, L. (2000). Gender Roles and Female Labour Migration A Qualitative Field Study of Female Migrant Workers in Beijing. PROP Report No. 29, Department of Sociology, Lund University. http://lup.lub.lu.se/luur/download?func=down loadFile\&recordOId=1888149\&fileOId=1888156.

Fan, C.C. (2000). Migration and gender in China. In: Lau, C.M. and Shen, J. (eds.). China Review. Hong Kong: Chinese University Press: 423-454.

Fan, C.C. (2008). China on the move: Migration, the state, and the household. London: Routledge.

Fan, C.C. (2004). Out to the city and back to the village: The experiences and contributions of rural women migrating from Sichuan and Anhui. In: Gaetano, A.M. and Jacka, T. (eds.). On the move: Women in rural-urban migration in contemporary China. New York: Columbia University Press: 177-206.

Fan, C.C. (2003). Rural-urban migration and gender division of labor in transitional China. International Journal of Urban and Regional Research 27(1): 24-47. doi:10.1111/1468-2427.00429.

Garcia, J., Hernández, P.J., and Lopez-Nicolas, A. (2001). How wide is the gap? An investigation of gender wage differences using quantile regression. Empirical Economics 26(1): 149-167. doi:10.1007/s001810000050.

Ge, Y.Y., Li, C.P., and Yin, Q. (2010). Study on factors of floating women's income in Jiangsu province based on Bayesian networks. In: Zeng, Z. and Wang, J. (eds.). Advances in Neural Network Research and Applications: 819-827. doi:10.1007/978-3-642-12990-2_95.

Gustafsson, B. and Li, S. (2000). Economic transformation and the gender earnings gap in urban China. Journal of Population Economics 13(2): 305-329. doi:10.1007/s001480050140.

Heckman, J. (1974). Shadow price, market wages, and labor supply. Econometrica 42(4): 679-694. doi:10.2307/1913937.

Heckman, J. (1979). Sample selection bias as a specification effort. Econometrica 47(1): 153-161. doi:10.2307/1912352.

International Labour Organization (ILO) (2008) Work, Income, and Gender Equality in East Asia: Acton Guide. Bangkok: ILO.

International Labour Organization (ILO) (2015). Global Wage Report 2014/15---Wages and income inequality. Geneva: International labour office. 
Qin et al.: Gender inequalities in employment and wage-earning among internal labour migrants

Jann, B. (2008). The Blinder-Oaxaca decomposition of linear models. Stata Journal 8(4): 453-479.

Jarrell, S.B. and Stanley, T.D. (2004). Declining bias and gender wage discrimination? A meta- regression analysis. Journal of Human Resources 39(3): 828-838. doi:10.2307/3558999.

Knight, J., Deng, Q., and Li, S. (2010). The puzzle of migrant labour shortage and rural labour surplus in China. Discussion Paper Series, University of Oxford. http://economics.ouls.ox.ac.uk/14813/1/paper494.pdf.

Knight, J. and Li, S. (2001). Unemployment duration and earnings of re-employed workers in urban China. China Economic Review 17(2): 103-119. doi:10.1016/j.chieco.2006.02.007.

Kunze, A. (2008). Gender wage gap studies: Consistency and decomposition. Empirical Economics 35(1): 63-76. doi:10.1007/s00181-007-0143-4.

Kunze, A. (2005). The evolution of the gender wage gap. Labour Economics 12(1): 7397. doi:10.1016/j.labeco.2004.02.012.

$\mathrm{Li}$, S. and Song, J. (2012). Changes in the gender wage gap in urban China, 1995-2007. CIBC Working Paper Series. http://economics.uwo.ca/cibc/working papers_docs/wp2011/Li_Song20.pdf.

Liang, Z. and Chen, Y.P. (2004). Migration and gender in China: An origin destination linked approach. Economic Development and Cultural Change 52(2): 423-443. doi:10.1086/380594.

Lin, T., Zhuang, J., Yarcia, D., and Lin, F. (2008). Income inequality in the People's Republic of China and its decomposition: 1990-2004. Asian Development Review 25(1-2): 119-136.

Lu, Y. and Wang, F. (2013) From general discrimination to segmented inequality: migration and inequality in urban China. Social Science Research 42(6): 14431456. doi:10.1016/j.ssresearch.2013.06.006.

Magnani, E. and Zhu, R. (2012). Gender wage differentials among rural-urban migrants in China. Regional Science and Urban Economics 42(5): 779-793. doi:10.1016/j.regsciurbeco.2011.08.001.

Mincer, J. (1974). Schooling, experience and earnings. New York: National Bureau of Economic Research. 
Mulligan, C. and Rubinstein, Y. (2008) Selection, investment and women's relative wage over time. Quarterly Journal of Economics 123(3): 1061-1110. doi:10.1162/qjec.2008.123.3.1061.

National Bureau of Statistics (NBS) (2012). 2011 Migrants survey report. National Bureau of Statistics of China (in Chinese).

National Bureau of Statistics (NBS) (2011). Demographic statistics from the 2010 Census. National Bureau of Statistics of China (in Chinese). http://www.stats.gov.cn.

Nicaise, I. (2001). Human capital, reservation wages, and job competition: Heckman's lambda reinterpreted. Applied Economics 33(3): 309-315. doi:10.1080/00036 840121810.

Oaxaca, R. (1973) Male and female wage differentials in urban labor markets. International Economic Review 14(3): 693-709. doi:10.2307/2525981.

Shen, Y. and Yao, Y. (2008). Does grassroots democracy reduce income inequality in China? Journal of Public Economics 92(10-11): 2182-2198. doi:10.1016/j. jpubeco.2008.04.002.

Smart, A. and Smart, J. (2001). Local citizenship: welfare reform urban/rural status, and exclusion in China. Environment and Planning A 33: 1853-1869. doi:10.1068/a3454.

Stanley, T.D. and Jarrell, S.B. (1998). Gender wage discrimination bias? A metaregression analysis. Journal of Human Resources 33(4): 947-973. doi:10.2307/ 146404.

Su, B. and Heshmati, A. (2011). Analysis of gender wage differential in China's urban labor market. Bonn: Institute for the Study of Labor (IZA Discussion Paper No. 6252). http://ftp.iza.org/dp6252.pdf.

Sutherland, D. and Yao, S. (2011). Income inequality in China over 30 years of reforms. Cambridge Journal of Regions, Economy and Society 4(1): 91-105. doi:10.1093/cjres/rsq036.

Taylor, G. (2011). China's floating migrants: Updates from the 2005 1\% Population Sample Survey. London: London School of Economics (Migration Studies Unit Working Papers No. 2011/07). http://www.lse.ac.uk/government/research/ resgroups/MSU/documents/workingPapers/WP_2011_07.pdf. 
Qin et al.: Gender inequalities in employment and wage-earning among internal labour migrants

Tuñón, M. (2006). Internal labour migration in China: features and responses. Beijing: ILO Office. http://www.ilo.org/beijing/what-we-do/publications/WCMS_1586 34/lang--en/index.htm.

United Nations (2015). Sustainable Development Goals. Transforming our world: the 2030 agenda for sustainable development. New York: United Nations. https://sustainabledevelopment.un.org/topics.

Wang, M. and Cai, F. (2008). Gender earnings differential in urban China. Review of Development Economics 12(2): 442-454. doi:10.1111/j.1467-9361.2008. 00450.x.

Wang, Z. (2010). Quintile regression study on gender wage difference. World Economic Papers 4: 51-64 (in Chinese).

Weichselbaumer, D. and Winter-Ebmer, R. (2005). A meta-analysis of the international gender wage gap. Journal of Economic Surveys 19(3): 479-511. doi:10.1111/j.0950-0804.2005.00256.x.

Ye, W.Z., Ge, X.F., and Ye, Y. (2005) Occupational development and its influence factors among female migrants in Xiamen city. Population Research 29(1): 6673 (in Chinese).

Zhang, L. and Dong, X. (2008). Male-female wage discrimination in Chinese industry: Investigation using firm-level data. Economics of Transition 16(1): 85-112. doi:10.1111/j.1468-0351.2007.00317.x. 


\section{Appendix A}

Figure A-1: Histogram of logarithmic hourly wages (ln_hwage) by gender

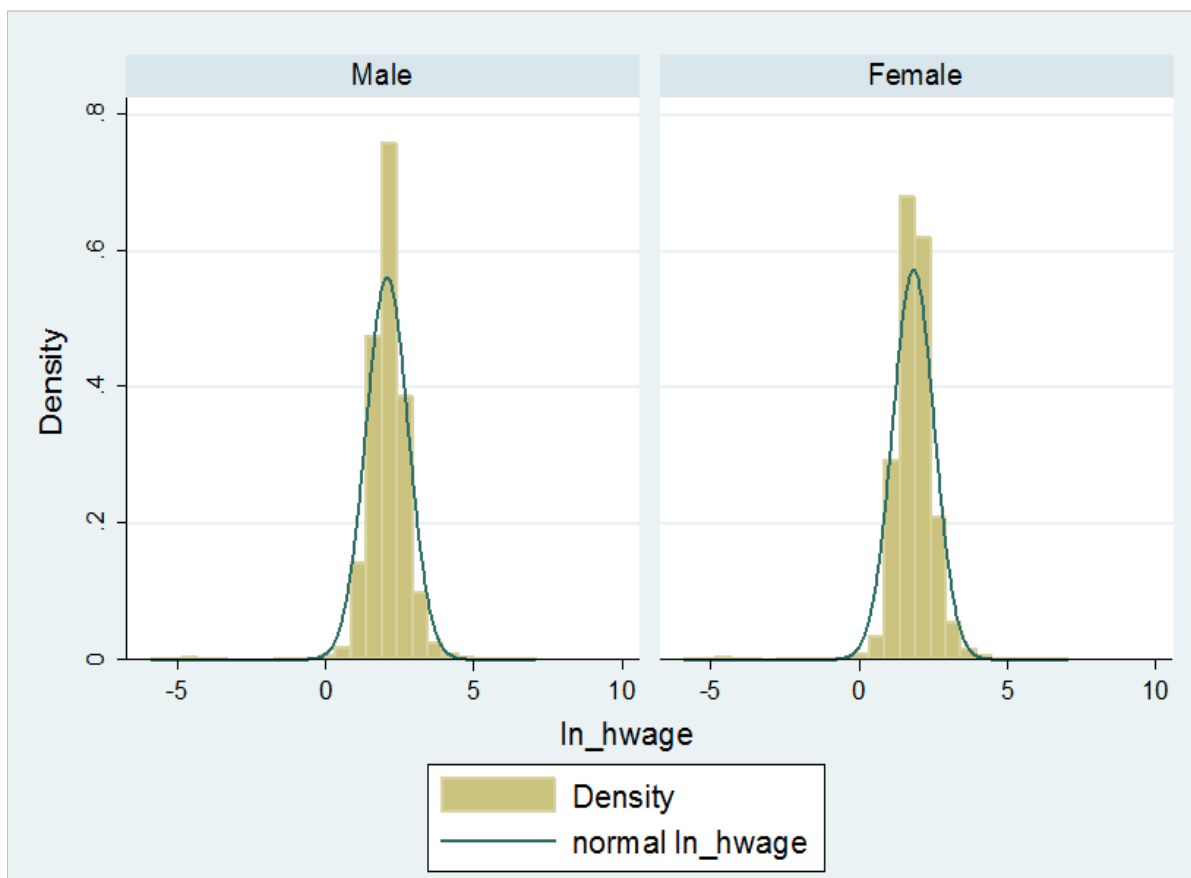

Histogram 
Qin et al.: Gender inequalities in employment and wage-earning among internal labour migrants

\section{Appendix B}

Based on Table 4, with the interaction term in the wage equation of male migrants with correction (Heckman), the effect of education on wages is represented by:

$-0.031 \times$ Rural $+0.085 \times$ Middle $+0.258 \times$ High $-0.004 \times$ Rural $\times$ Middle $-0.114 \times$ Rural $\times$ High

Therefore, the effect of high school education on wages is $0.258-0.145 \times$ Rural. For male migrants with urban hukou (rural=0), the effect of high school education on wages is 0.258 . So, for male migrants with urban hukou, the effect of high school education on wages is 0.258 higher than that of primary school education. For those with rural hukou (rural=1), the effect of high school education is $0.258-0.145=0.113$. This indicates that for male migrants with rural hukou, the effect of high school education on wages would be only 0.113 higher than that of primary school education.

For the wage equation of female migrants with correction (Heckman), the effect of education on wages looks like:

$-0.168 \times$ Rural $-0.009 \times$ Middle $+0.162 \times$ High $+0.099 \times$ Rural $\times$ Middle $+0.032 \times$ Rural $\times$ High

The effect of middle school education on wages is $-0.009-0.069 \times$ Rural. For female migrants with urban hukou (rural=0), the effect of middle school education on wages is -0.009 , but this is not significant. So, for female migrants with urban hukou, those with middle school education have the same wages as those with primary school education. For those with rural hukou (rural=1), the effect of middle school education is -0.069 . This indicates that for female migrants with rural hukou, the effect of middle school education on wages would be 0.069 lower than that of primary school education.

For male migrants, high school education has positive effect on wages, but the difference is much smaller for rural hukou male migrants than for their urban hukou counterparts. For female migrants, middle school education has no significant effect on wages for urban hukou; but has significant negative effect on wages for their rural hukou counterparts. This suggests that education does not reduce the rural hukou migrant disadvantage for either males and females. 